\title{
Analisis Perspektif Pengguna Terhadap Website Faculty of Communication, Visual Art and Computing (FCVAC) Menggunakan Teknik Systyem Usability Scale (SUS)
}

\author{
Nia Adila1, Putri Melani' ${ }^{2}$, Novia Sukma \\ Informatics Departement, Bina Darma University, Palembang, Idnonesia \\ 1,2,3Information System Departement, Universitas Bina Darma, Palembang, Idonesia \\ Email: 1niaadila@binadarma.ac.id, 2putrimelani@binadarma.ac.id, \\ 3noviasukma@binadarma.ac.id
}

\begin{abstract}
This practical work aims to evaluate and assess the level of user usefulness at the Universiti Selangor Faculty of Communication, Visual Art and Computing (FCVAC) website. The method used in collecting data needed in writing this practical work report is to use a questionnaire created in accordance with the System Usability Scale (SUS) technique filled out online using Google Form, while the writing technique uses descriptive techniques. And based on the observation of the author during practical work on the use of users on the website of the Faculty of Communication, Visual Art and Computing (FCVAC) Universiti Selangor, its usability can be accepted by the user so that the website can be used properly.
\end{abstract}

Keywords: Website, System Usability Scale, User

\section{PENDAHULUAN}

Perkembangan teknologi informasi saat ini kian pesat, sehingga menjadi media yang efektif untuk mencari dan menyebarkan informasi. Dan dengan penerapan teknologi informasi yang baik membuat proses penyebaran informasi menjadi lebih cepat, mudah dan murah serta tanpa batasan jarak dan waktu. Penerapan teknologi informasi dalam beberapa bidang yaitu baik pada bidang pemerintahan maupun bidang Pendidikan saat ini berinisiatif mengembangkan pelayanan publik melalui jaringan komunikasi dan informasi dalam bentuk situs yaitu website. 
Vol. 1, No. 1, January 2020 e-ISSN: 2775-2496

https://journal-computing.org/index.php/journal-cisa/index

Website merupakan salah satu jenis layanan/fasilitas yang disediakan oleh internet yang paling banyak digunakan disamping layananlayanan yang lainnya, website wajib mempunyai konten informasi dengan kualitas yang baik bagi pengguna awam dalam penggunaannya, untuk mendapatkan sebuah informasi yang diperlukan dalam bidang pendidikan pada instansi perguruuan tinggi website menjadi salah satu layanan informasi kepada mahasiswa, dosen, alumni, karyawan dan bahkan masyarakat umum.

Dengan adanya layanan informasi berbasis website pada perguruan tinggi yang ada salah satunya Universiti Selangor ( UNISEL ) yang sudah cukup lama menerapkan layanan informasi berbasis website, dan memiliki beberapa website pada setiap fakultasnya. Website Faculty Of Communication, Visual Art And Computing (FCVAC) salah satunya dimana website ini aktif sebagai informasi bagi mahasiswa dan dosen maupun layanan publik. Dengan adanya website Faculty of Communication, Visual Art And Computing (FCVAC) yang sudah diterapkan, tapi tidak menutup kemungkinan juga ada beberapa faktor yang akan membuat website tidak digunakan pengguna dengan baik. Sehingga dibutuhkan evaluasi apa saja faktor yang akan mempengaruhi pada tingkatan kualitas dan kebergunaan website terhadap pengguna, pada wesite Faculty of Communication, Visual Art And Computing ( FCVAC) akan dinilai dan di analisa menggunakan suatu evaluasi dan mencari letak kekurangannya. Untuk melakukan evaluasi tersebut berdasarkan pandangan pengguna dapat digunakan teknik pengukuran usability, karena usability merupakan teknik pengukuran yang dilakukan sesuai dengan pengalaman pengguna terhadap sebuah sistem. Pengukuran dengan teknik usability berfokus pada penilaian tingkat kebergunaan sistem yang disediakan, pengukuran usability menjadi sangat penting mengingat usability mampu untuk menggambarkan apakah pengguna dapat menerima sistem yang dihasilkan atau tidak [1].

Dalam melakukan evaluasi dengan teknik usability dapat dilakukan dengan dua cara yaitu (1) yang melibatkan ahli dan (2) yang melibatkan pengguna dari sistem itu sendiri. Objek yang menjadi sasaran evaluasi juga bervariasi baik sistem yang dijalankan berbasis website, desktop, maupun berbasis mobile. Fokus dari penilaian usability sebenarnya terdapat lima aspek yaitu: learnability, efficiency, memorability, errors, dan atisfaction. Dari kedua cara. 
https://journal-computing.org/index.php/journal-cisa/index

evaluasi usability, teknik evaluasi yang dilakukan berdasarkan pandangan pengguna. Pada System Usability Scale (SUS) sendiri memiliki kelebihan yaitu, (1) proses evaluasi lebih mudah dimengerti oleh responden, (2) dapat melibatkan sampel yang sedikit namun dapat menggambarkan hasil yang maksimal, dan (3) dapat membedakan dengan jelas antara aplikasi yang dapat dan tidak dapat digunakan [1]. Pengukuran evaluasi berdasarkan pandangan pengguna dengan teknik System Usability Scale (SUS) dilakukan dengan perhitungan yang jelas atau dengan kata lain memiliki teknik perhitungan sendiri. Dengan demikian hasil pengukuran dapat dipertanggungjawabkan untuk itu sebagai langkah pemastian nilai kebergunaan terhadap website Faculty of Communication, Visual Art And Computing (FCVAC) yang dihasilkan maka digunakan System Usability Scale (SUS) sebagai teknik evaluasi pandangan pengguna, oleh karena itu laporan ini berjudul Analisis Perspektif Pengguna Terhadap Website Faculty Of Communication, Visual Art And Computing (FCVAC) Menggunakan Teknik System Usability Scale (SUS).

\subsection{Tujuan}

1) Untuk pemetaan tingkat kebergunaan terhadap website Faculty of Communication, Visual Art And Computing (FCVAC) dengan teknik System Usability Scale (SUS).

2) Untuk identifikasi permasalahan yang berkaitan dengan fungsi terhadap website Faculty of Communication, Visual Art And Computing (FCVAC) dengan teknik System Usability Scale (SUS).

\section{Metode Penelitian}

\subsection{Responden Pengujian}

System Usability Scale (SUS) dalam menentukan responden tidak memiliki konsep yang baku atau tidak ada penentuan secara khusus dari teori dasarnya [1]. Kondisi tersebut disebabkan responden dari system usability scale (SUS) merupakan pengguna akhir dari sebuah produk perangkat lunak yang akan dilakukan evaluasi atau pengujian. Dalam beberapa kajian menunjukkan system usability scale (SUS) menggunakan responden yang berbeda-beda bahkan sampai dengan empat ratus sembilan puluh sembilan responden. Dalam pengujian yang lain juga ada yang menggunakan responden sangat sedikit yaitu lima dan sepulu responden Penggunaan jumlah responden yang berbeda merupakan independensi dan sesuai dengan kebutuhan peneliti itu sendiri. Seorang 
Vol. 1, No. 1, January 2020 e-ISSN: 2775-2496

https://journal-computing.org/index.php/journal-cisa/index

peneliti diberikan kebebasan dalam menentukan responden sesuai dengan rumusan atau teknik pengambilan sampel peneltian [2]. SUS juga tidak memerlukan jumlah sampel yang banyak sehingga dapat meminimalkan biaya [3], oleh karena itu peneliti dalam penelitian ini hanya mengambil 20 sampel secara acak sebab 20 sampel sudah cukup untuk mengetahui apakah sebuah website pada Universiti Selangor itu baik bagi pengguna [4].

\subsection{Metode Penyajian}

Dalam melakukan evaluasi ini metode penyajian hasil penelitian digunakan metode dekriptif. Metode dekriptif adalah suatu metode yang mengemukakan masalah dengan cara mengumpulkan data-data yang disajikan untuk menggambarkan karakteristik suatu keadaan atau objek menelitian dan mengambil kesimpulan [5].

\subsection{Metode Pengumpulan Data}

Dalam proses penelitian metode pengumpulan data yang digunakan adalah menggunakan kuesioner. Kuesioner yang dibuat sesuai dengan teknik system usability scale seperti pada Tabel 1 yang diisi secara online dengan menggunakan Google Form.

\subsection{Waktu dan Tempat}

Penelitian ini dilakukan selama 2 minggu mulai dari tanggal 25 januari sampai 8 februari 2020 yang berlokasi di Universiti Selangor kota Bestari Jaya, Malaysia.

\subsection{Metode Pengukuran System Usability Scale (SUS)}

Dalam proses penelitian metode pengumpulan data yang digunakan adalah menggunakan kuesioner. Kuesioner yang dibuat sesuai dengan teknik system usability scale seperti pada Tabel 1 yang diisi secara online dengan menggunakan Google Form. Kuesioner ini disebarkan selama 2 minggu mulai tanggal 25 januari sampai 8 februari 2020.

Untuk mengukur hasil perhitungan evaluasi, system usability scale memiliki teknik tersendiri dengan membedekan antara instrument yang bernomor ganji dan bernomol genap. dan pengujian SUS memiliki 10 pernyataan sebagai alat pengujian, Sedangkan instrumen pengujian 
Vol. 1, No. 1, January 2020 e-ISSN: 2775-2496

https://journal-computing.org/index.php/journal-cisa/index

untuk system usability scale (SUS) terdapat sepuluh pernyataan yang menjadi tolak ukur pengujian seperti pada Tabel 1 [6] [7] [8]. Instrumen pengujuian system usability scale (SUS) dapat digunakan untuk pengujian bermacam jenis pengujian mulai dari website, sistem informasi dan perangkat lunak berbasis seluler [9].

Tabel 1. Penyatan SUS [10]

\begin{tabular}{|c|c|c|}
\hline No & Pernyataan & Skala \\
\hline 1 & Saya akan ingin lebih sering menggunakan aplikasi ini & $1-5$ \\
\hline 2 & $\begin{array}{l}\text { Saya merasa aplikasi ini tidak harus dibuat serumit } \\
\text { Ini }\end{array}$ & $1-5$ \\
\hline 3 & Saya pikir aplikasi mudah untuk digunakan & $1-5$ \\
\hline 4 & $\begin{array}{l}\text { Saya membutuhkan bantuan dari orang teknis untuk } \\
\text { menggunakan aplikasi ini }\end{array}$ & $1-5$ \\
\hline 5 & $\begin{array}{l}\text { Saya menemukan fitur pada aplikasi terintegrasi } \\
\text { dengan baik }\end{array}$ & $1-5$ \\
\hline 6 & Saya pikir ada ketidaksesuaian dalam aplikasi ini & $1-5$ \\
\hline 7 & $\begin{array}{l}\text { Saya merasa kebanyakan orang mudah untuk } \\
\text { mempelajari aplikasi dengan sangat cepat }\end{array}$ & $1-5$ \\
\hline 8 & $\begin{array}{l}\text { Saya menemukan aplikasi sangat rumit untuk } \\
\text { Digunakan }\end{array}$ & $1-5$ \\
\hline 9 & Saya percaya diri untuk menggunakan aplikasi ini & $1-5$ \\
\hline 10 & Saya perlu belajar sebelum menggunakan aplikasi ini & $1-5$ \\
\hline
\end{tabular}

\subsection{Metode Pengujian}

Dalam melakukan pengujian SUS memiliki 10 instrument seperti pada Tabel 1. Dari Tabel 1 dapat dijelaskan bahwa kuesioner SUS menggunakan 5 poin skala Likert. Responden diminta untuk memberikan penilaian "Sangat tidak setuju", "Tidak setuju", "Netral", "Setuju", dan "Sangat setuju" atas 10 item pernyataan SUS sesuai dengan penelitian subyektifnya. Jika responden merasa tidak menemukan skala yang tepat, responden harus mengisi titik tengah skala pengujian [11].

Setiap pernyataan instrument dilakukan kesimpulan satu persatu dari total keseluruhan responden dengan menjumlahkan skor nilai tiap pernyataan pada kuesioner, kemudian dicari nilai rata-rata dari penjumlahan skor nilai kuesioner. Untuk mengetahui kesimpulan dari responden, dilakukan pembulatan angkah dari nilai rata-rata. Adapun 
https://journal-computing.org/index.php/journal-cisa/index

aturan pembulatan bilangan kesatuan terdekat (Buku Master SD/MI, Ringkasan Materi Dan Kumpulan Rumus Lengkap [12].

1) Jika bilangann itu lebih kecil dari 5 maka dibulatkan ke bawah.

2) Jika bilangan itu lebih besar dari 5 maka dibulatkan keatas.

\subsection{Metode Perhitungan Skor System Usability Scale (SUS)}

Dalam melakukan pengujian usability baik heuristic evaluation (HE) maupun system usability scale (SUS) memiliki pebedaan dalam perhitungan hasil pengujian. Perbedaan tersebut terjadi disebabkan oleh jumlah penguji pada heuristic evaluation (HE) dan system usability scale (SUS). Heuristic evaluation dalam melakukan pembototan penilaian dimulai dari 0 (nol) sampai dengan 5 (lima). Untuk melakukan perhitungan hasil pengujian nilai dari pembobotan penguji (expert) dijumlahkan untuk masing-maisng instrumen dan kemudian dilakukan perhitungan rata-rata untuk masing-msaing instrument seperti pada Tabel 1 . Pembobotan angka 0 (nol) sampai dengan 5 (lima) memiliki makna berupa [13]:

1) 0: tidak memiliki masalah usability

2) 1: memiliki masalah cosmetic problem

3) 2: minor usability problem; perlu perbaikan

4) 3: major usability problem; perlu perbaikan yang mempengaruhi proses

5) 4: usability catastrophe; perlu tindakan desain ulang

Sedangkan dalam perhitungan system usability scale (SUS) memiliki aturan yang berbeda dengan heuristic evaluation (HE). Peberdaan tersebut terletak pada nomor ganjil dan genap instrumen pengujian, berikut adalah cara perhitungan hasil pengujian system usability scale (SUS) [14] :

1) Penyataan instrumen nomor ganjil skala jawaban instrumen dikurangi 1.

2) Pernyataan instrumen nomor genap maka 5 dikurangi skala jawaban instrumen.

3) Hasil penilaian skala 0 - 4 (4 merupakan jawaban terbaik).

4) Melakukan pernjulahan jawaban kemudian dikali dengan 2.

5) Menentukan nilai rerata jawaban instrumen pengujian semua responden [15].

\subsection{Penentuan Hasil Perhitunga Skor SUS}


Vol. 1, No. 1, January 2020 e-ISSN: 2775-2496

https://journal-computing.org/index.php/journal-cisa/index

Pandang yaitu acceptability, grade scale, dan adjective rating. Acceptability terdapat tiga tingkatan yang terdiri dari not acceptable, marginal (rendah dan tinggi), dan acceptable. Sedangkan grade scale terdiri dari A, B, C, D dan F. Untuk adjective rating lebih banyak tingkatan yaitu worst imaginable, poor, ok, good, excelent dan best imanginable. Dari ketiga penilaian system usability scale (SUS) seperti yang diperlihatkan pada Gambar 5 bahwa acceptability digunakan untuk melihat tingkat penerimaan pengguna terhadap perangkat lunak, grade scale untuk melihat tingkatan (grade) perangkat lunak, dan adjective rating untuk melihat rating dari perangkat lunak yang dihasilkan seperti pada Gambar 1.

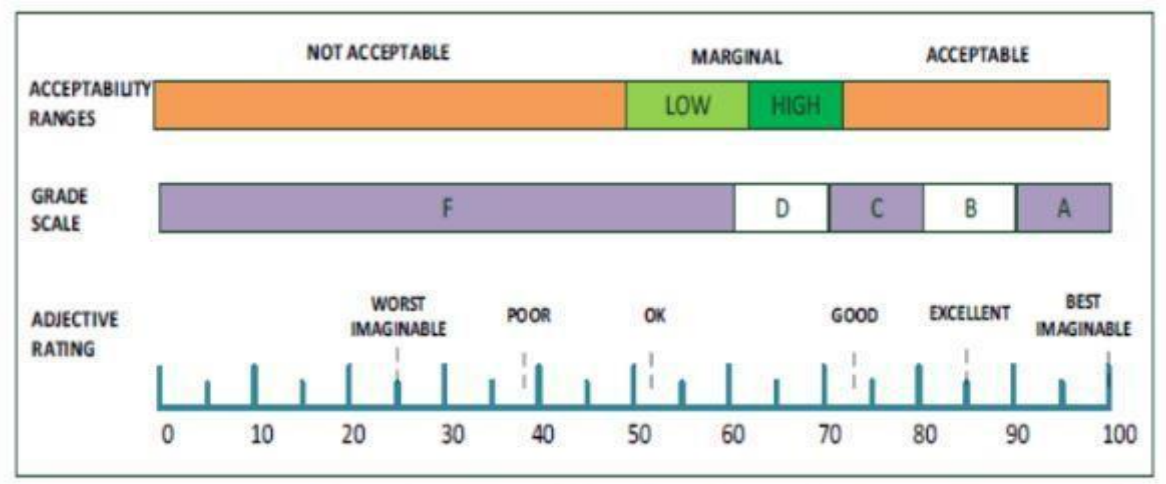

Gambar 1. Penentuan Hasil Penilaian [1]

Selain dari ketiga cara tersebut system usability scale (SUS) memiliki cara lain dalam melakukan penentuan hasil peneilaian yaitu dengan cara SUS score percentile rank. Penentuan hasil penilaian berdasarkan SUS score percentile rank dilakukan secara umum berdasarkan hasil perhitungan penilaian pengguna. SUS score percentile rank memiliki perbedaan dengan acceptability, grade scale, adjective rating yang dikelompokkan menjadi tiga kategori seperti pada Gambar 2. Berikut adalah ketentuan penentuan penilaian pada SUS score percentile rank:

1) Grade A : dengan skor $>=80,3$

2) Grade B : dengan skor $>=74$ dan $<80,3$

3) Grade C : dengan skor $>=68$ dan $<74$.

4) Grade D : dengan skor $>=51$ dan $<68$.

5) Grade F : dengan skor lebih $<51$. [1] 
Vol. 1, No. 1, January 2020 e-ISSN: 2775-2496

https://journal-computing.org/index.php/journal-cisa/index

\subsection{Objek Penelitian}

Objek yang menjadi bahan penelitian adalah website FCVAC Universiti Selangor. Website ini dapat diakses dengan cara mengakses tautan http://fcvac.unisel.edu.my/. Tampilan utama dari website ini seperti yang diperlihatkan pada Gambar 2.

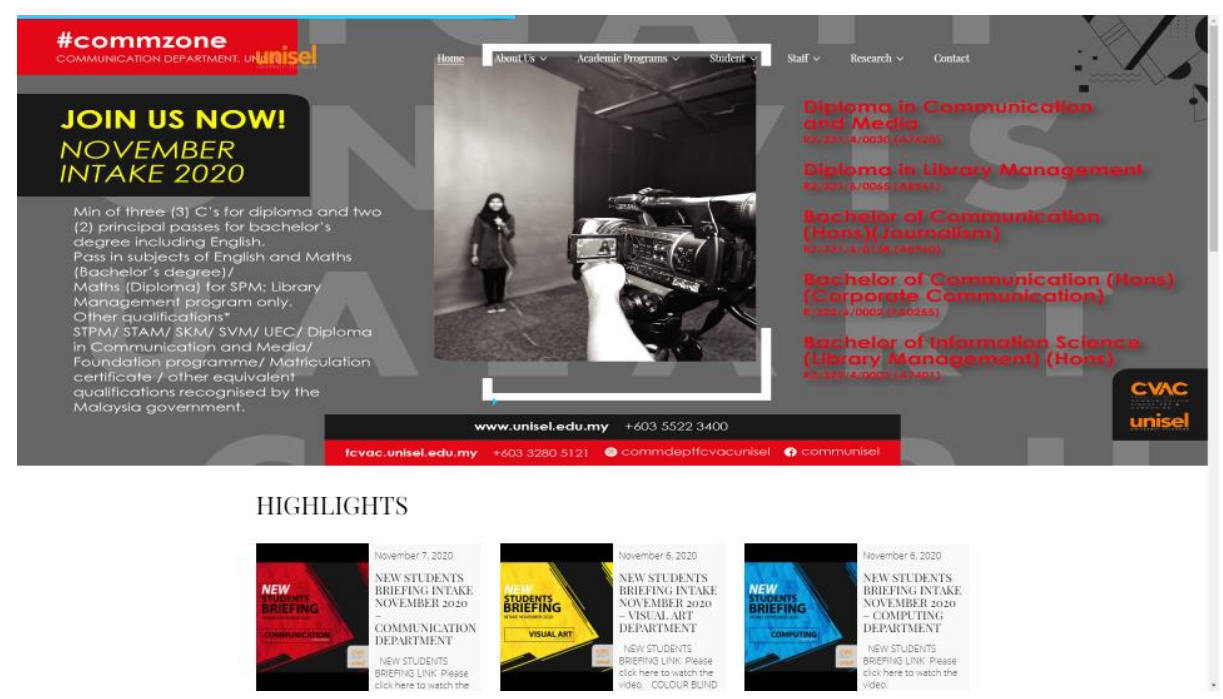

Gambar 2. Tampilan Utama Website FCVAC Universiti Selangor

\section{Hasil Dan Pembahasan \\ 3.1 Responden}

Dalam melakukan evaluasi usability jumlah responden menjadi sangat penting. Kondisi tersebut disebabkan jumlah responden yang sedikit akan berdampak semakin besarnya peluang untuk menemukan permasalahan. Kondisi tersebut juga akan terjadi pada hal sebaliknya. Dengan demikian didalam melakukan Evaluasi ini ditentukan jumlah responden yaitu sebanyak dua puluh responden. Untuk itu karateristik responden dalam melakukan evaluasi terdiri dari 3 karakteristik.

Tanggapan yang diperoleh dari 20 responden, berdasarkan program akademiknya. $70 \%$ atau sama dengan 14 orang mahasiswa dari program akademik Departement of Computing, 25\% atau sama dengan 5 orang mahasiswa dari program akademik Departement of Visual Art, dan 5\% atau sama dengan 1 orang mahasiswa dari program akademik Departement of Communication seperti pada Gambar 3. 
Vol. 1, No. 1, January 2020 e-ISSN: 2775-2496

https://journal-computing.org/index.php/journal-cisa/index

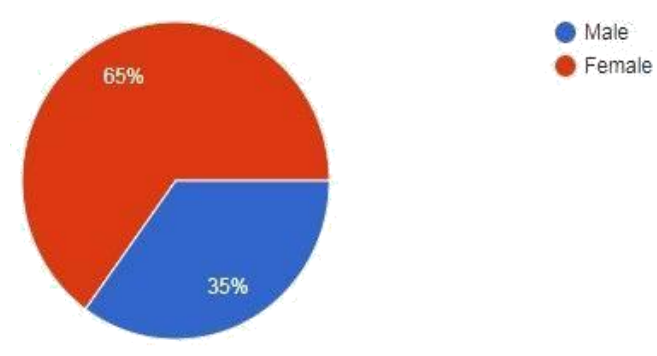

Gambar 3. Karakteristik Program Akademik

Berdasarkan jenis kelaminnya, 65\% atau sama dengan 13 orang mahasiswa perempuan, dan $35 \%$ atau sama dengan 7 orang mahasiswa laki-laki seperti pada Gambar 5.

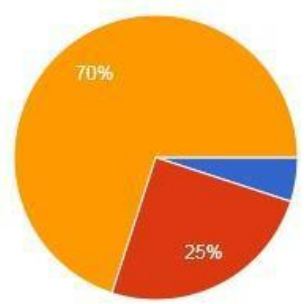

Gambar 2. Karakteristik Jenis Kelamin

Sedangkan berdasarkan semesternya, 5\% atau sama dengan 1 orang mahasiswa semester $1,5 \%$ atau sama dengan 1 orang mahasiswa semester 2, 15\% atau sama dengan 3 orang mahasiswa semester 3, 15\% atau sama dengan 3 orang mahasiswa semester 4, 10\% atau sama dengan 2 orang mahasiswa semester $6,5 \%$ atau sama dengan 1 orang mahasiswa semester 7, 35\% atau sama dengan 7 orang mahasiswa semester $8,5 \%$ atau sama dengan 1 orang mahasiswa semester 9, dan $5 \%$ atau sama dengan 1 orang mahasiswa semester lainnya. Apabila tanggapan yang diperoleh hasilnya dipersentasekan, maka hasilnya ditunjukkan pada Gambar 3.
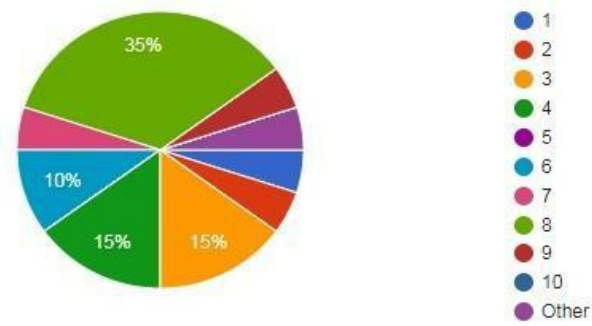
Gambar 3. Karakteristik Semester

Hasil kuesioner kemudian dihitung dengan rumus yang telah ditentukan untuk mendapatkan skor SUS. Hasil jawaban responden ditampilkan pada Tabel 2, dimana skala jawaban yang digunakan yaitu dari 1 sampai 5. Skala 5 menyatakan sangat setuju dengan pertanyataan instrumen dan skala 1 menyatakan sangat tidak setuju dengan pernyataan instrumen.

\subsection{Usability}

Berdasarkan pernyataan dari 20 responden, setiap pernyataan dapat terlihat pada Tabel 2 atau dapat disimpulkan rekapan data nilai mentah setiap pernyataan dari kuisioner yang diberikan kepada setiap responden:

Tabel 1. Nilai Setiap Pernyataan

\begin{tabular}{lllllllllll}
\hline Responden & & \multicolumn{7}{c}{ Jawaban Responden } \\
& P1 & P2 & P3 & P4 & P5 & P6 & P7 & P8 & P9 & P10 \\
\hline R1 & 4 & 3 & 4 & 2 & 4 & 3 & 4 & 3 & 4 & 3 \\
R2 & 5 & 2 & 4 & 2 & 4 & 2 & 4 & 4 & 4 & 3 \\
R3 & 3 & 2 & 2 & 4 & 4 & 3 & 3 & 2 & 3 & 3 \\
R4 & 2 & 2 & 2 & 2 & 2 & 2 & 2 & 2 & 2 & 2 \\
R5 & 3 & 2 & 5 & 4 & 3 & 3 & 4 & 3 & 3 & 4 \\
R6 & 4 & 3 & 4 & 4 & 3 & 4 & 4 & 4 & 4 & 4 \\
R7 & 4 & 4 & 4 & 4 & 4 & 4 & 4 & 4 & 4 & 4 \\
R8 & 4 & 3 & 4 & 4 & 3 & 3 & 4 & 3 & 4 & 4 \\
R9 & 4 & 2 & 3 & 3 & 2 & 3 & 3 & 3 & 2 & 1 \\
R10 & 3 & 4 & 2 & 2 & 4 & 3 & 4 & 3 & 4 & 3 \\
R11 & 2 & 2 & 2 & 3 & 3 & 2 & 3 & 2 & 2 & 3 \\
R12 & 4 & 3 & 3 & 3 & 3 & 3 & 3 & 4 & 4 & 4 \\
R13 & 2 & 1 & 2 & 2 & 2 & 2 & 2 & 2 & 2 & 3 \\
R14 & 5 & 4 & 4 & 4 & 4 & 4 & 4 & 4 & 4 & 3 \\
R15 & 4 & 4 & 4 & 4 & 4 & 4 & 4 & 4 & 4 & 4
\end{tabular}


Vol. 1, No. 1, January 2020 e-ISSN: 2775-2496

https://journal-computing.org/index.php/journal-cisa/index

$\begin{array}{ccccccccccc}\text { R16 } & 3 & 3 & 3 & 4 & 3 & 3 & 3 & 4 & 4 & 3 \\ \text { R17 } & 4 & 3 & 5 & 3 & 5 & 3 & 5 & 5 & 5 & 5 \\ \text { R18 } & 4 & 3 & 4 & 4 & 4 & 3 & 5 & 3 & 4 & 3 \\ \text { R19 } & 4 & 4 & 4 & 4 & 4 & 4 & 4 & 4 & 4 & 4 \\ \text { R20 } & 2 & 3 & 2 & 3 & 2 & 3 & 3 & 2 & 2 & 3 \\ \text { JUMLAH } & 70 & 57 & 67 & 65 & 67 & 61 & 72 & 65 & 69 & 66 \\ \text { NILAI P } & \mathbf{3 . 5} & \mathbf{2 . 8 5} & \mathbf{3 . 3 5} & \mathbf{3 . 2 5} & \mathbf{3 . 3 5} & \mathbf{3 . 0 5} & \mathbf{3 . 6} & \mathbf{3 . 2 5} & \mathbf{3 . 2 5} & \mathbf{3 . 3}\end{array}$

\subsection{Hasil Evaluasi}

Berdasarkan hasil kuisioner yang diberikan kepada responden yaitu mahasiswa FCVAC maka hasil rekapitulasi jawaban responden seperti pada Tabel 3. Kuisioner yang diberikan kepada responden berdasarkan instrumen system usability scale seperti yang diperlihatkan pada Tabel 1. Skala jawaban yang digunakan yaitu dari 1 sampai dengan 5, dimana 5 menyatakan sangat setuju dengan pernyataan instrument dan 1 menyatakan sangat tidak setuju dengan pernyataan instrument.

Jawaban responden seperti yang pada Tabel 2 merupakan jawaban responden yang belum dilakukan perhitungan sesuai dengan teknik pengukuran dengan system usability scale. Untuk itu dari jawaban pada Tabel dilakukan perhitungan untuk langkah-langkah perhitungan system usability scale "(1) Instrumen nomor ganjil skala jawaban dikurangi 1. (2) Instrumen nomor genap 5 dikurangi skala jawaban. (3) Skala 0 sampai dengan 4 (empat respon paling positif)". Dari ketentuan 1,2 dan 3 maka hasil konversi atau perhitungan seperti yang diperlihatkan pada Tabel 4. Pada Tabel 3 dan Tabel 4 merupakan hasil jawaban awal dan hasil jawaban yang telah dilakukan perhitungan. Dimana kolom $\mathrm{P}$ mengindikasikan sebagai pernyataan dan $\mathrm{R}$ sebagai responden

Dari proses menggunakan SUS maka hasil evaluasi seperti pada Tabel 2 dapat diketahui yaitu 68.875 sesuai dengan perhitungan SUS, untuk mendapatkan bagaimana perspektif user maka hasil akhir dapat dicocokkan sesuai ketentuan seperti yang diperlihatkan pada Gambar 2. Sesuai dengan ketentuan tersebut maka dapat dikatakan bahwa website FCVAC University Selangor dari sisi adjective rating termasuk kelompok good, dari sisi grade scale termasuk kelompok D, dan dari sisi acceptability termasuk kelompok marginal (high). Dengan kondisi 
Vol. 1, No. 1, January 2020 e-ISSN: 2775-2496

https://journal-computing.org/index.php/journal-cisa/index

tersebut maka Website FCVAC University Selangor tersebut dapat diterima usability nya oleh user dan dapat digunakan dengan baik.

\section{Penutup}

Dari penjelasan di atas, maka dapat disimpulkan bahwa sesuai dengan judul "Analisis perspektif pengguna terhadap website Faculty of communication, visual art and computing (FCVAC) menggunakan teknik System Usability Scale (SUS)" penulis menyimpulkan System Usability Scale (SUS) melakukan pengujian yang lebih menekankan perspektif pengguna akhir sehingga hasil evaluasi akan lebih sesuai dengan keadaan nyata dan metode ini juga tidak memerlukan jumlah sampel yang banyak oleh karena itu penulis hanya mengambil 20 responden secara acak.

Adapun hasil evaluasi yang dapat diketahui yaitu dari data nilai setiap pernyataan dan data perhitungan setiap responden yang di jumlahkan sehingga mendapatkan hasil nilai akhir 68.875. Dan sesuai dengan ketentuan, jumlah akhir website termasuk grade scale kelompok D maka dapat dikatakan bahwa website FCVAC Universiti Selangor tersebut dapat diterima usability nya oleh user sehingga dapat digunakan dengan baik.

\section{DAFTAR PUSTAKA}

[1] U. Ependi, T. B. Kurniawan, and F. Panjaitan, "System Usability Scale Vs Heuristic Evaluation: a Review," Simetris J. Tek. Mesin, Elektro dan Ilmu Komput., vol. 10, no. 1, pp. 65-74, 2019, doi: 10.24176/simet.v10i1.2725. https://www.bachelorstudies.co.id/universitas/Malaysia/Universit i-Selangor-(UNISEL)/ (accessed Apr. 30, 2020).

"sejarah unisel 1," 2020.
https://en.wikipedia.org/wiki/University_of_Selangor (accessed Apr. 29, 2020).

[4] H. A. HASSAN, "sejarah unisel2," universiti selangor, 2014. https://free.facebook.com/universelangor/photos/a.11507073190 22 30/741535669255730/?type=3\&_rdc=18_rdr (accessed Apr. 30, 2020).

[5] R. Tianingrum and H. Sopiany, "Analisis Kemampuan Pemahaman Matematis Siswa SMP Pada Materi Bangun Ruang Sisi Datar," in Prosiding seminar nasional matematika dan pendidikan matematika (SESIOMADIKA), 2017, pp. 440-446. 
https://journal-computing.org/index.php/journal-cisa/index

[6] A. Herliana and P. M. Rasyid, "Sistem Informasi Monitoring Perkembangan Software pada tahap Development Berbasi Web," no. 1, pp. 41-50, 2016.

[7] Azhar Susanto, Sistem Infromasi Akuntansi. 2013.

[8] Budiyanto, "DENGAN PENDEKATAN MODEL DELONE DAN MCLEAN (Studi Kasus Implementasi Billing System Di RSUD Kabupaten Sragen ) TESIS Untuk Memenuhi Sebagian Persyaratan Mencapai Derajat Magister Program Studi Magister Akuntansi Minat Utama: Akuntansi Sektor Publik," Tesis, p. 83, 2009, doi: $10.1159 / 000448528$.

[10] J. N. Anamofa, "Analisis Pengaruh Gaya dan Situasi Kepemimpinan Terhadap Iklim Kerja Universitas Halmahera," vol. 1, 2017.

[11] A. P. S. Cruz, “済無No Title No Title," J. Chem. Inf. Model., vol. 53, no. 9, pp. 1689-1699, 2013, doi: 10.1017/CB09781107415324.004.

[12] R. Harminingtyas, "analisis layanan website sebagai media promosi,media transaksi dan media informasi danpengaruhnya terhadap brand image perusahaan pada hotel ciputra dikota semarang," STIE SEMARANG, vol. 6, no. 3, pp. 37-57, 2014.

[13] H. Nurmi, "Membangun Website Sistem Informasi Dinas Pariwisata," J. Edik Inform., vol. 1, no. 2, pp. 1-6, 2014.

[14] "pengertian pengguna," 2020. https://translate.google.com/translate?u=https://en.wikipedia.org /wi ki/User_(computing)\&hl=id\&sl=en\&tl=id\&client=srp (accessed Apr. 12, 2020).

[15] J. S. Informasi, "Evaluasi Website Dengan Menggunakan System Usability Scale (SUS) Pada Perguruan Tinggi Swasta di Palembang," vol. 4, pp. 89-98, 2018. 